\title{
DŘEVĚNÁ KONSTRUKCE DOMU Z ČESKÝCH BUDĚJOVIC Z PRVNÍ POLOVINY 14. STOLETÍ
}

\author{
LADISLAV ČAPEK - JIŘÍ MILITKÝ
}

\begin{abstract}
Abstrakt: Cílem př́spěvku je rozbor jedinečně zachované dřevěné konstrukce, která byla objevena při záchranném archeologickém výzkumu parcely v Radniční ulici čp. 138/11 v roce 1993. Dřevěná konstrukce byla interpretována jako základ roubené stavby nadzemního domu, který se nacházel v uliční čáre při domovém průčelí. Rozbor keramiky z výplně objektu datuje tuto stavbu do první poloviny 14. století. V př́spěvku jsou hodnoceny dalši pozůstatky drevěných konstrukcí nalezené při archeologických výzkumech a stavebně historických průzkumech $v$ historickém jádru města. Je rekonstruován také prostorový vývoj zástavby na dotčené parcele a řešena otázka vztahu dřevěné stavby $k$ dalším archeologicky prozkoumaným objektům.
\end{abstract}

Klíčová slova: městský dům - dřevohliněná architektura - středověk - keramika - České Budějovice 14. století.

\section{The wooden structure of a house in České Budějovice from the first half of the 14th century}

Abstract: This contribution analyses a uniquely preserved wooden structure uncovered during rescue archaeological research in a plot in Radnični Street 138/11, České Budějovice in 1993. The wooden structure was interpreted as a base of a timbered house built above the ground, located on a street front of house frontages. The analysis of pottery from the fill of the feature dates the construction to the first half of the 14th century. The contribution assesses further remains of wooden structures yielded by archaeological and building-historical research in the historical centre of the city. The spatial development of the built-up area is reconstructed as well, and the article also discusses the issue of the relationship between the timbered house and other archeologically investigated features.

Key words: urban house - wood and earth architecture - Middle Ages - pottery - České Budějovice 14th century.

\section{Úvod}

V květnu roku 1993 proběhl na parcele čp. 138/11 (416)ำ v Radniční ulici, nacházející se v jihozápadním koutu historického jádra při městské hradbě, záchranný archeologický výzkum (obr. 1). Výzkum, který provádělo záchranné archeologické oddělení Jihočeského muzea pod vedením Jiřího Militkého, byl vyvolán stavební demolicí domu v souvislosti s výstavbou hotelu U Solné brány (Militký 1993). Stavebně historický průzkum, který proběhl v roce 1990, potvrdil stáŕí konstrukcí a architektonických detailů několikrát přestavovaného objektu, který vznikl na půdoryse gotického domu, který nejpozději ke konci 18. století získal konečnou podobu hloubkové trojtraktové dispozice se dvěma bočními kř́́dly a středovým průjezdem, které od prostoru dvora oddělovalo zadní příčné křídlo (Muk-Urban 1990). Během archeologického výzkumu se podařilo prozkoumat několika sondami jak situace $\mathrm{v}$ původně zastavěné a později zbořené části domu (v průjezdu a v levém bočním traktu), tak na jeho dvorovém prostranství v zadní části parcely. Cílem výzkumu bylo vedle zjištění nejstarších sídlištních situací od počátku založení města získat představu o stavebním a prostorovém vývoji zástavby a rovněž potvrdit stáří městské hradby, která přiléhala k západní straně parcely.

Během záchranného výzkumu byl objeven zahloubený objekt polozemnice (suterén) a další objekty odpadního charakteru, které je možné datovat do třetí třetiny 13. století. Objekty a plošný nárůst zvrstvení, zejména $\mathrm{v}$ zadní části parcely, prokazují intenzivní osídlení již v době krátce po založení města v roce 1265 . Z mladších středověkých situací ze 14 . století pozornost zasluhuje

1 První číslo uvádí současné číslo popisné platné od roku 1978, číslo za lomítkem je číslem orientačním použivaným od roku 1955 . Číslo v závorce představuje nejstarší číslování domů, které je uvedeno v topografii J. Kubáka (1973). 
především objev dřevěné konstrukce interpretované jako základ srubové stavby (Militký-Zavřel 1994, 220; Militký 1995, 82), jejíž podrobný rozbor včetně movitých nálezů ze zásypových vrstev je předmětem této studie. Dřevěná konstrukce je ve městě vzácným dokladem krátké fáze existence dřevohliněné architektury předcházející výstavbě zděných jader gotických domů.
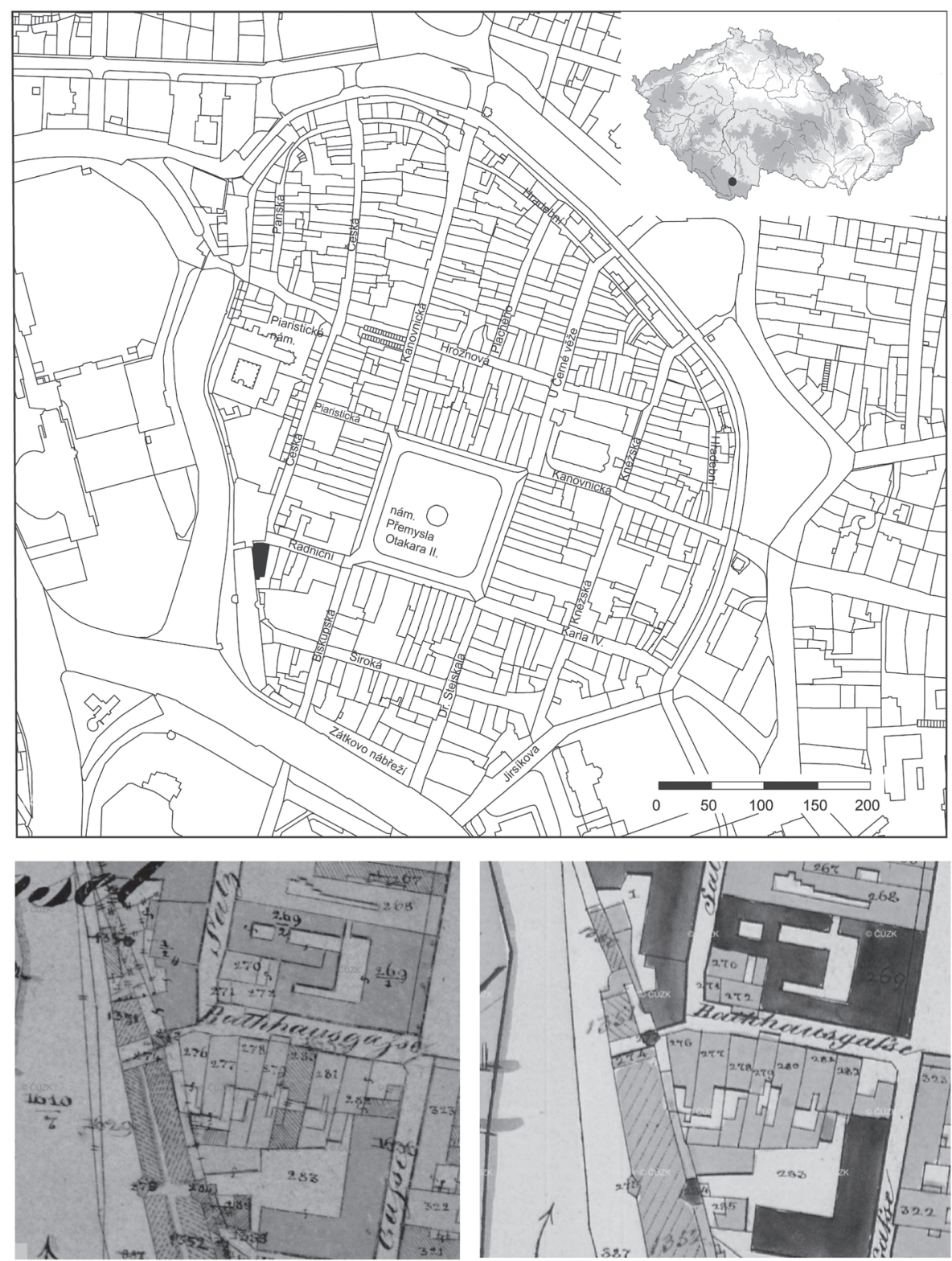

Obr. 1. Poloha parcely čp. 138/11 (416) v Radniční ulici na plánu města a mapách stabilního katastru (indikační skica a císařský otisk - č. parcely 276).

Abb. 1. Lage der Parzelle Konskriptionsnr. 138/11 (416) in der Straße Radniční im Stadtplan und auf den Karten des stabilen Katasters (Indikationsskizze und kaiserlicher Abdruck - Parzellennr. 276). 
Článek zhodnocuje výsledky staršího záchranného archeologického výzkumu, který byl realizován v době na počátku nebývale narůstající stavební činnosti ve městě, na niž nebylo dostatečně připraveno ani archeologické oddělení Jihočeského muzea ani orgány památkové péče. Jako reakce na množství stavebních akcí v souvislosti s rekonstrukcí historických domů ve městě bylo v roce 1993 založeno samostatné oddělení záchranných archeologických výzkumů při Jihočeském muzeu (Zavřel 2018, 382). Na kompletní prozkoumání dotčené parcely a její zástavby byly tehdy velmi omezené nejen časové, ale i ekonomické možnosti, které nedovolily prozkoumat všechny nálezové situace v úplnosti. ${ }^{2}$ Přesto se díky nasazení pracovníků muzea pod vedením J. Militkého podařilo provést tehdy standardní kresebnou a fotografickou dokumentaci všech zkoumaných sond, která umožňuje s odstupem několika let od skončení výzkumu rekonstrukci a kritickou revizi výsledků výzkumu. Svojí kvalitou dnes tato dokumentace již neobstojí, výrazným limitem je například absence výškopisného zaměření nebo podrobnější deskripce stratigrafických jednotek - tehdy poprvé částečně zaznamenaných prostřednictvím kontextových listů. Přesto se domníváme, že nelze rezignovat na publikování starších výzkumů z prostředí města, zvláště těch, které přispívají k poznání vývoje osídlení na parcelách a stavební podoby dřevohliněných a zděných městských domů.

\section{Popis nálezové situace}

Dřevěná konstrukce byla objevena na severní straně parcely čp. 138/11 v místech před bývalým průčelím domu v dokumentovaném základovém vkopu (sonda 9), zhruba 120 až $130 \mathrm{~cm}$ od současného povrchu. V nejspodnější části sondy v hloubce 125 až $130 \mathrm{~cm}$ od současného povrchu se podařilo zachytit dřevěnou konstrukci, která měla pravidelný půdorys (obr. 2 a 3). Konstrukce byla založena do výkopu přibližně 50 až $60 \mathrm{~cm}$ od původního povrchu, který tvořila ulehlá hnědošedá hlinitá vrstva (s. j. 9003) nacházející se nad černošedou hlinitou vrstvou (s. j. 9007) půdního

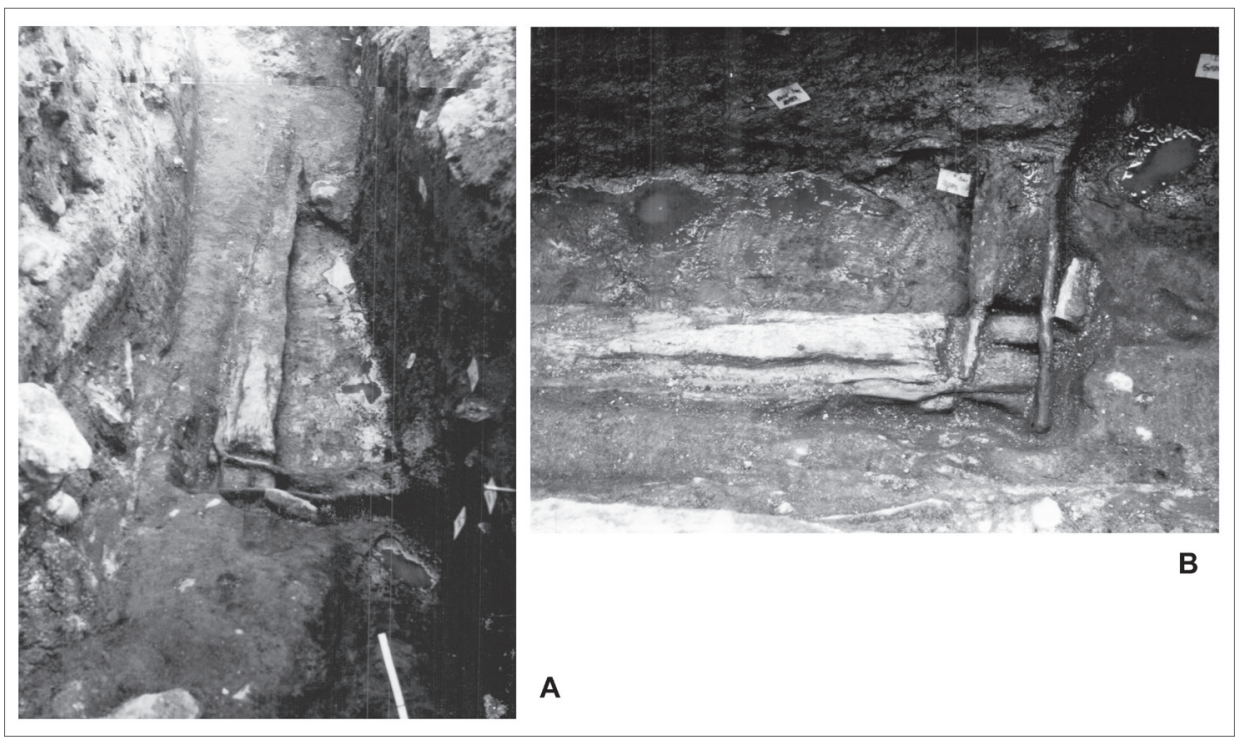

Obr. 2. Fotodokumentace dřevěné konstrukce domu: A - průběh konstrukce ve směru západ-východ při uliční čáře; B - detail tesařské vazby dřeva. Foto J. Militký.

Abb. 2. Fotodokumentation der Holzkonstruktion des Hauses: A - West-Ost-Verlauf der Konstruktion an der Straßenflucht; B - Detail der Holzverbindung. Foto J. Militký.

2 Ústní sdělení J. Militkého. 
typu. Dřevěná konstrukce byla tvořena dlouhým ztesaným trámem o průměru $18 \times 16 \mathrm{~cm}$ ve směru východ-západ, na jehož koncích nasedaly dva další kolmé trámy o průměru $16 \times 16 \mathrm{~cm}$, tvořící dvě nároží. V západním nároží se dochovala dobře viditelná tesařská vazba dřeva v podobě pravoúhlého čepu na rybinu vytvářejícího nárožní spoj stěny. Východní nároží bylo zachováno jen stínem dřeva. Šiřka celé konstrukce činila $4 \mathrm{~m}$. Hrana dřevěné konstrukce se nacházela př́ímo v uliční čáře a téměř se kryla s průčelím mladšího zděného gotického domu (obr. 6 a 7).

Bohužel se při archeologickém výzkumu nepodařilo prozkoumat celý rozsah dřevěné stavby, jež zasahovala pod zděné konstrukce pravého bočního traktu domu, kde byl archeologický průzkum investorem znemožněn.

29

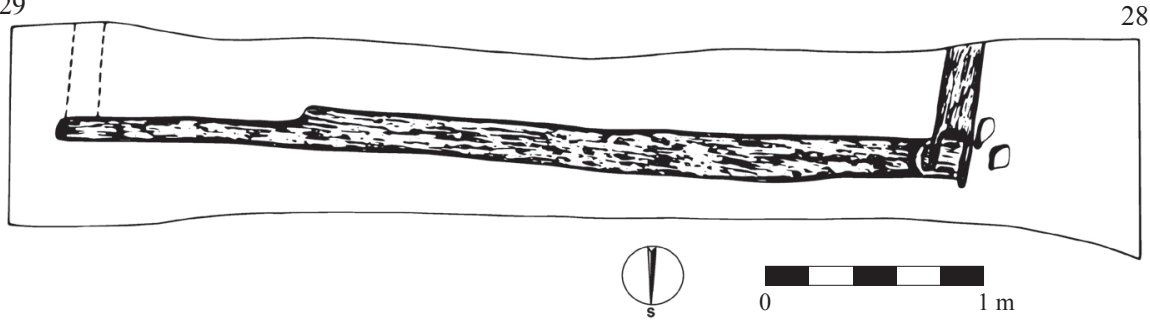

Obr. 3. Půdorys sondy $9 \mathrm{~s}$ dřevěnou konstrukcí domu. Upravil L. Čapek.

Abb. 3. Grundriss von Sondierschnitt 9 mit Holzkonstruktion des Hauses. Bearbeitung L. Čapek.

Výplň objektu tvořily dvě vrstvy (obr. 4). Nejspodnější tenkou $10 \mathrm{~cm}$ vysokou hnědou hlinitou vrstvu (s. j. 9001) lze interpretovat jako tenkou ušlapanou vrstvu hliněné podlahy z doby existence objektu, která obsahovala jen ojediněle malé zlomky keramiky. Horní okrovohnědá hlinito-písčitá vrstva (s. j. 9002) o mocnosti 45 cm tvořila zásyp objektu, a lze ji považovat za zánikovou vrstvu z doby ukončení funkce objektu. Z této vrstvy pochází početnější soubor keramiky, včetně importů, a také několik železných předmětů. Jiné nálezy nebyly ze zánikové vrstvy získány.

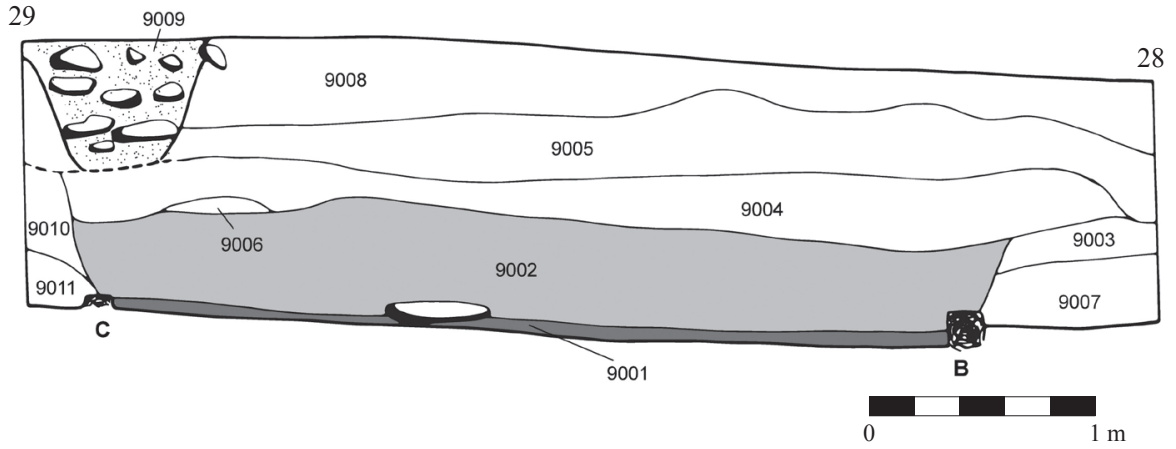

Obr. 4. Dokumentovaný jižní profil sondy 9. Upravil L. Čapek.

Abb. 4. Dokumentiertes Südprofil von Sondierschnitt 9. Bearbeitung L. Čapek. 


\section{Rozbor keramiky}

Rozbor keramiky vychází z deskripčního systému vytvořeného pro českobudějovickou keramiku (nejkompletněji publikován v Čapek-Militký a kol. 2016, včetně přehledů typů okrajů a výzdoby). Deskripce keramických tříd vycházela z upraveného systému makroskopického studia (např. Nováček-Tetour 2003; Procházka 2007, 241-245) posuzující: 1) strukturu keramické hmoty (kompaktnost, zrnitost, charakter plastické a neplastické složky, množství a velikost neplastických prríměsí - ostřiva), 2) výpal (tvrdost výpalu a charakter výpalu - oxidační/redukční/smíšený), 3) úpravu povrchu (textura a modelace, charakter povrchové úpravy, hlazení, leštění, engoba, glazura) a 4) barvu (vnějšího a vnitřního povrchu, barvu střepu na lomu).

Deskripce okrajů vycházela ze základního hierarchického členění okrajů podle systému skupina - typ - varianta (srov. Vařeka 1998, 125-126). Skupinu charakterizuje stejný způsob základního utváření horní koncové části okraje (např. zesílení, vytažení, přehnutí), které se pak dělí na jednotlivé typy podle dalšího druhu úpravy okraje (seříznutí, prožlabení, podžlabení, podseknutí apod.), v rámci jejichž typologické řady jsou rozlišovány jednotlivé varianty lišící se v detailech profilace a úpravy okraje. Podobně je klasifikována výzdoba keramiky, kdy skupinu charakterizuje shodný způsob provedení výzdoby pomocí rytí, vrypů, vseků, kolků apod., které se dále dělí na jednotlivé typy a varianty.

Z vrstvy 9001 - podlahové hlinité vrstvy pochází pouze osm malých rozšlapaných zlomků keramiky. Z toho pět zlomků náleží grafitovým třídám (2× CB3002, 1× CB3007 a 2× CB3008) a tři redukčním třídám (1× CB4002 a 2× CB4005). Z určitelných zlomků byl zastoupen pouze jeden okraj hrnce typu nízkého okruží H.17.5 o průměru $14 \mathrm{~cm}$ (obr. 5A:1) a nezdobená výdut'.

Početnější byl soubor z vrstvy 9002 představující sekundárně uložený zásyp objektu. Bylo v něm nalezeno 84 zlomků keramiky. Přehled zastoupení keramických tříd ukazuje graf (graf 1). Nejvíce byla zastoupena režná modrošedá redukční třída s př́iměsí písku CB4005 (29 \%, 24 zl.) následována hnědošedou třídou s příměsí hrubšího šupinatého grafitu CB3002 (22 \%, 18 zl.). Dále se vyskytovala redukční třída s př́íměsí hrubšího písku nekvalitního redukčního výpalu CB4002 (16 \%, 13 zl.) a tmavě šedá až černá redukční třída CB4003 (11\%, 9 zl.) vyznačující se očazením povrchu. Zastoupena byla také redukční třída s prŕíměsí jemně drceného grafitu CB3015 (6 zl.). Zbývající třídy náležely ke světlým až okrově hnědým třídám oxidačního výpalu s jemnější příměsí grafitu a černým jádrem - CB3007 (4 zl.) a CB3008 (1 zl.). K nim patří i jim podobná třída s jemně plavenou engobou - CB3010 (3 zl.). Po dvou zlomcích jsou doloženy třídy CB3029 a CB4001 náležící ke skupině redukční režné keramiky s písčitou příměsí. Poměr redukčních a grafitových keramických tř́id byl přibližně ze dvou třetin ve prospěch redukční keramiky.

Z keramických tvarů byly v souboru zastoupeny hrnce $(8 \times)$, poklice $(4 \times)$, zásobnice $(4 \times)$, doložen je i jeden miskovitý kahan. Spektrum typů okrajů hrnců bylo poměrně variabilní (obr. 5B:2-10). Zastoupeny byly okraje typu nepravého okruží oboustranně prožlabeného H.17.8 (1×), klasického okruží vně prožlabeného H.17.6 (1×) a nízké okruží H.17.5 (1×). Ke starším „hradištním“ typům náleží okraj mírně oboustranně protažený H.1.5 (1×) a zesílený okraj H.2.2 (1×) s vnitřním prožlabením. Mladší typy pak reprezentují okraje zesílené - ovalené a podseknuté H.12.1 (1×) a H.12.2 (1×) a okraj přehnutý H.12.7 (1×). Doložen je také kyjovitý okraj zásobnice, který řadíme ke kratším typům Z.8.1 (obr. 5B:1). Poklice náleží po jednom okraji k typům PO.2.1, PO.3.1 a PO.6.2, které reprezentují okraje zvonovitých poklic (obr. 5B:11-13).

Zdobeno bylo celkem devět fragmentů. Zastoupena je široká rytá vývalková šroubovice R.04.03 (2×) a R.04.05 (1×), dále jednoduchá užší rytá rýha R.02.01 (1×). Ze starších typů výzdoby jsou doloženy v jednom případě šikmé vrypy V.01 a kombinovaná výzdoba pomocí vrypů a rytých rýh RV.01.03. Na jednom zlomku je výzdoba pomocí nezřetelného radélka. Na okraji zásobnice se nacházely atypické vseky přes sebe (obr. 5B:1). Na jednom dnu nádoby byla zjištěna nečitelná hrnčířská značka.

Zvláštní pozornost zasluhují dva atypické zlomky, které se vymykají běžné českobudějovické produkci keramiky. V prvním případě se jedná o okraj a hrdlo miniaturní nádobky 

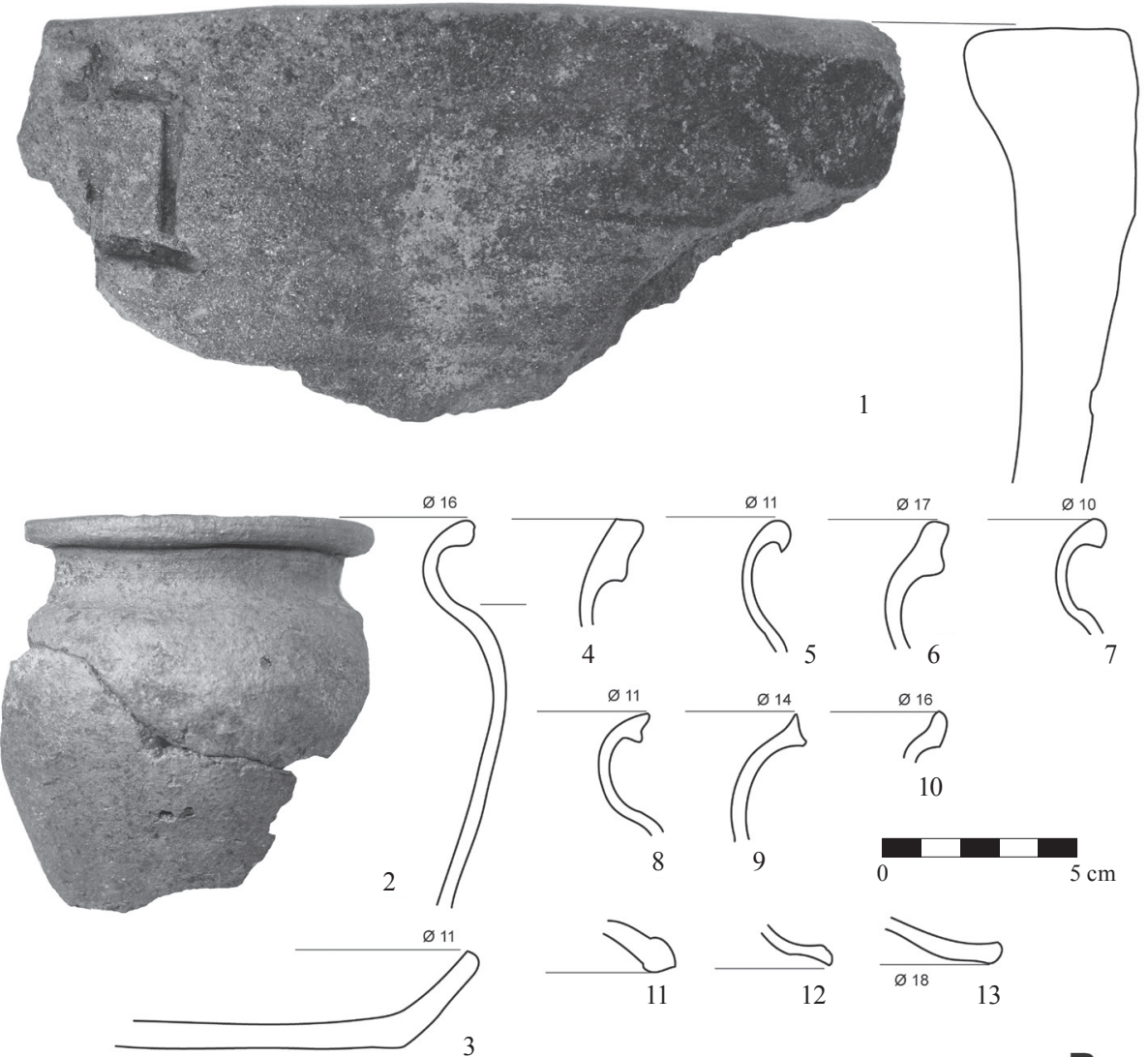

B
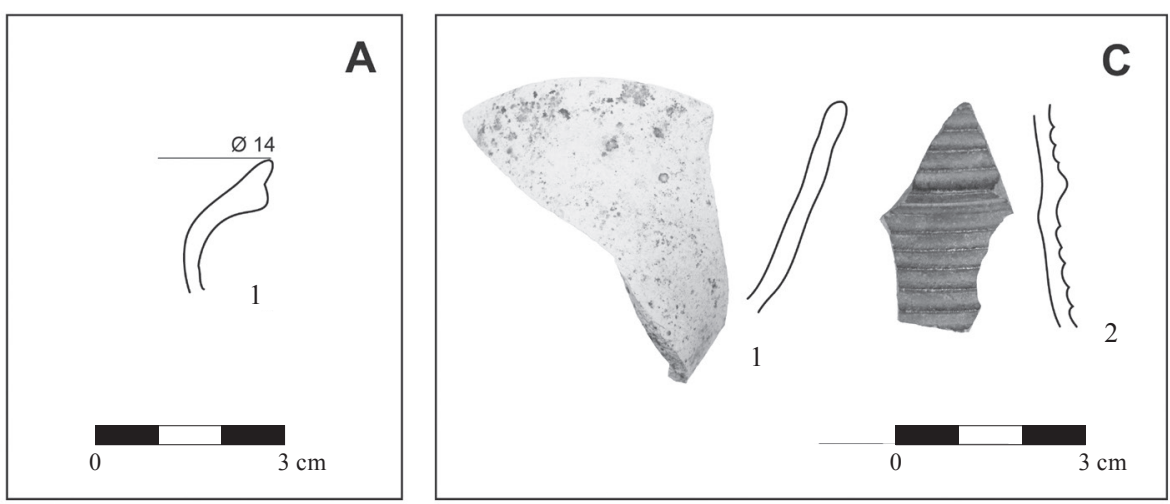

Obr. 5. Středověká keramika z vrstev dřevěné stavby: A - vrstva 9001; B - vrstva 9002; C - keramické importy ve vrstvě 9002 . Kresba a foto L. Čapek.

Abb. 5. Mittelalterliche Keramik aus den Schichten des Holzbaus: A - Schicht 9001; B - Schicht 9002; C - Keramikimporte in Schicht 9002. Zeichnung und Foto L. Čapek. 


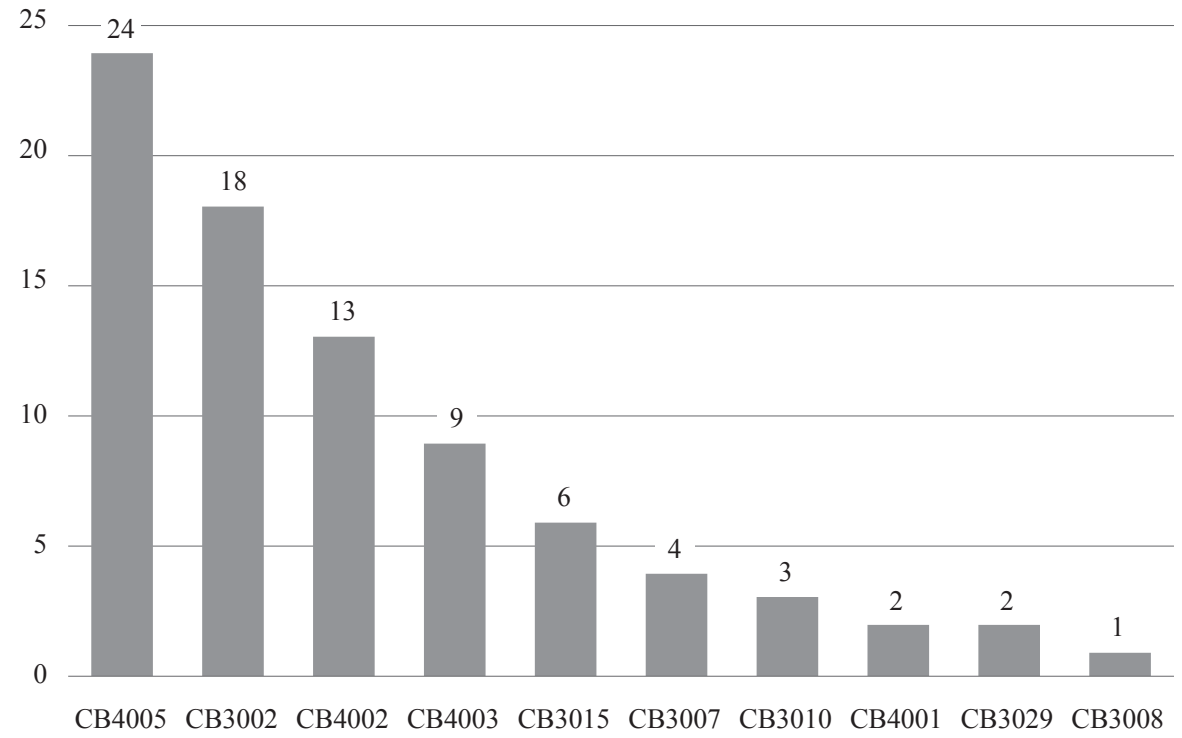

Graf 1. Zastoupení keramických tř́íd z vrstvy 9002.

Diagram 1. Die in Schicht 9002 vertretenen Keramikklassen.

(patrně džbánku), jež byla vyrobena z jemně plavené bělavé hmoty odpovídající keramické třídě CB3026 (obr. 5C:1). Ve druhém případě se jedná o zlomek kameninové nádoby hnědé barvy zdobené oběžnými hrotitými vývalky a vystupující lištou (obr. 5C:2).

Miniaturní nádobka patří ke skupině jemně plavené kaolinitické keramiky, jejiž původ je předpokládán v širším teritoriu západní Evropy a jež je hojně rozšířena jako import v českých a moravských městech před i po polovině 13. století (např. Richter 1982, 82-83 129-130; Klápště 1983, 458; Klápště a kol. 2002, 21). Produkční centra této keramiky jsou předpokládána v sasko-durynské oblasti (Beutmann-Kenzler 2006, 485-494). Zlomek druhé nádoby má původ v německých dílnách vyrábějících kameninu. Jen přibližně ji můžeme zařadit do pravděpodobného okruhu waldenburské kameniny (Hoffmann 1995, 43-96), která patř́í mezi nejrozšířenější druhy kamenin dostávající se jako import do našeho prostředí, a to již od 14. století. Podle tvaru by se mohlo jednat o válcovité hrdlo kameninového džbánu, podobné výrobky měly pod okrajem charakteristickou jednu nebo dvě profilované lišty (srov. Scheidemantel-Schifer 2005, 257-260).

\section{Další nálezy}

Kromě keramických nálezů byla objevena v zásypové vrstvě 9002 také čepel železného nože (obr. 6). Čepel měla délku 12,3 cm, šířku $1,5 \mathrm{~cm}$ a tloušt'ku $0,2 \mathrm{~cm}$. Celková hmotnost železného nože po konzervaci byla $14,7 \mathrm{~g}$. Dále byla nalezena trojice železných hřebíků dochovaných v podobě dříků a v jednom případě i dříku s hlavičkou. Bohužel stav intenzivní koroze neumožnil detailnější typologický rozbor. Lze konstatovat, že nůž patřil do běžného kuchyňského vybavení dřevěné stavby a železné hřebíky sloužily k upevňování dřevěných spojovacích konstrukcí. 

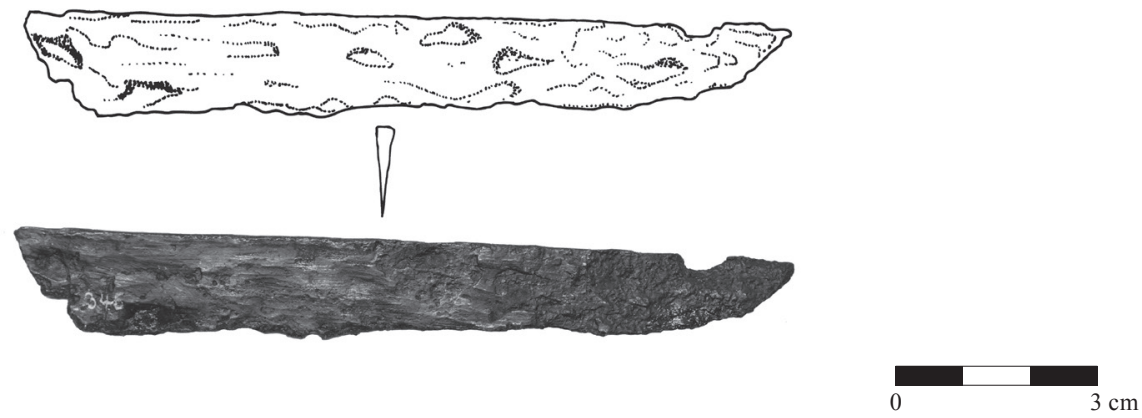

Obr. 6. Čepel želeného nože z výplně 9002 dřevěné stavby. Kresba a foto L. Čapek.

Abb. 6. Klinge des Eisenmessers aus Verfüllung 9002 des Holzbaus. Zeichnung und Foto L. Čapek.

\section{Datování}

Při výzkumu dřevěné konstrukce byl odebrán vzorek dřeva, bohužel dendrochronologické analýzy později provedeny nebyly a vzorek je dnes nezvěstný (informace J. Militký). Datování doby existence a zániku stavby je možné odvodit pouze na základě rozboru stratigrafických vztahů a keramiky samotné, na základě její komparace s podobně datovanými soubory z Českých Budějovic a okolí.

Z podlahové úrovně (s. j. 9001) pochází zlomek okraje nízkého okruží H.17.5. - tyto tvary okrajů se objevují v Českých Budějovicích nejdříve na přelomu 13. a 14. století a jsou výhradně vázány na redukční keramiku, která se začíná výrazně prosazovat po roce 1300 na úkor domácí produkce keramiky grafitové vycházející z pozdněhradištních tradic výroby (Čapek-Militký a kol. 2016, 142-143). Také jinde v jižních Čechách je výskyt okrajů okruží kladen do období přelomu 13. a 14. až první poloviny 14. století (Hrdlička-Richter-Smetánka 1966, 671, 667, obr. 198; Vařeka 1993, 103; Ernée-Vařeka 1998, 222-223, Abb. 2:3; Richter-Krajíc 2001, 157).

Variabilnější skladbu okrajů vykazuje soubor ze zánikové vrstvy (s. j. 9002). Zastoupeny jsou v něm okraje spadající ještě do průběhu 13. století - oboustranně protažený H.1.5 a zesílený okraj s vnitřním prožlabením H.2.2. V Českých Budějovicích se tyto okraje objevují v nejstarších horizontech A a B1, datovaných do třetí třetiny až závěru 13. století (Čapek-Militký a kol. 2016, 140-142). Mladší okraje nižších okruží H.17.5 a H.17.6 spolu s okraji ovalenými a podseknutými H.12.1 a H.12.2, které včetně okraje přehnutého H.12.7 jednoznačně odpovídají typům okrajů objevujícím se poprvé v průběhu 14. století. Také ve výzdobě převládají jak starší archaické prvky 13. století, které představují vrypy a značky na dnech nádob, tak mladší v podobě vývalkové šroubovice a radélka, objevující se od počátku 14. století (Čapek-Militký a kol. 2016, 143).

Složení keramických tř́id, kde je v souboru zastoupena $v$ jedné třetině grafitová a ze dvou třetin redukční keramika, odpovídá českobudějovickému horizontu B2, pro nějž je typický souběžný výskyt obou skupin (Čapek-Militký a kol. 2016, 142-143). V tomto horizontu se projevuje doznívání pozdních grafitových tříd s jemnější substancí grafitických hornin (zejm. CB3007, CB3008 a CB3010), které se vyskytují s hrubozrnnější písčitou keramikou nepř́liš kvalitního redukčního výpalu (CB4001, CB4002), na niž pak navazuje kvalitní redukční režná třída CB4005. Výrazný nástup keramiky redukčního výpalu je kladen do doby kolem roku 1300. Od tohoto roku až do průběhu první poloviny 14. století klademe dataci horní zásypové vrstvy objektu (s. j. 9002) $\mathrm{s}$ dřevěnou konstrukcí. 


\section{Stavební a prostorový vývoj parcely}

Nové zpracování výsledků archeologického výzkumu, které doposud byly publikovány pouze předběžně (Militký-Zavřel 1994, 220-221; Militký 1995, 82-84), umožňuje náhled do stavebního a prostorového vývoje parcely v Radniční ulici čp. 138/11. Rekonstrukce stavebního a prostorového vývoje parcely se opírá o rozbor stratigrafických vztahů a datování kontextů na základě keramiky (podrobně bude publikována na jiném místě) v komparaci s výsledky stavebně historického průzkumu.

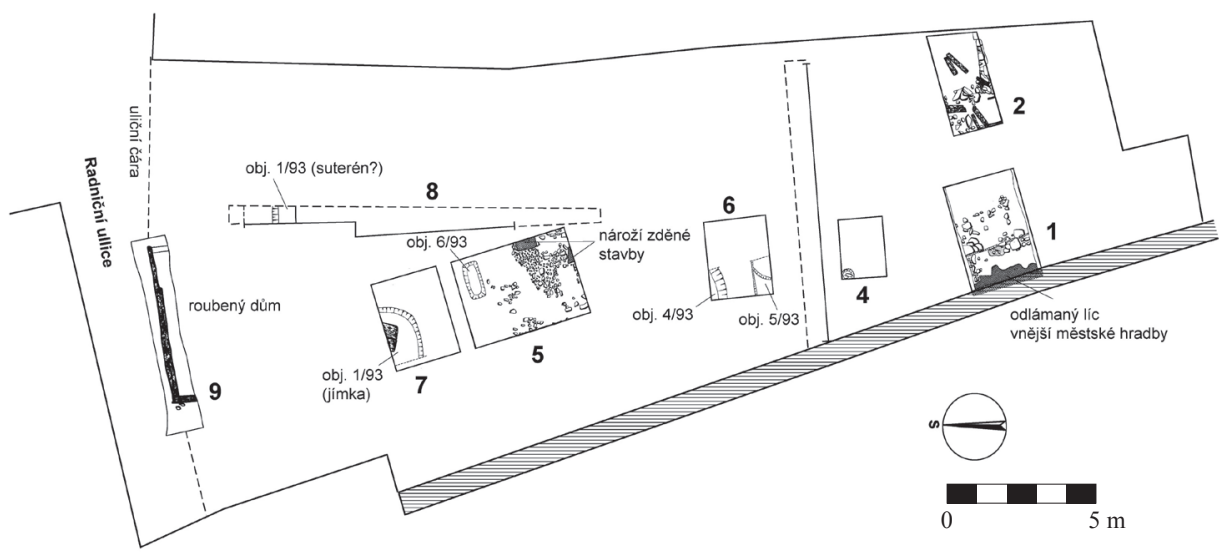

Obr. 7. Rekonstrukce sídelního vývoje na parcele čp. 138/11 v Radniční ulici v první a ve druhé fázi z 3. třetiny 13. až poloviny 14. století. Vytvořil L. Čapek.

Abb. 7. Rekonstruktion der Siedlungsentwicklung auf der Parzelle Konskriptionsnr. 138/11 in der Straße Radniční in der ersten und zweiten Phase des Zeitraums 3. Drittel 13. bis Mitte 14. Jahrhundert. Erstellt von L. Čapek.

Stavebně historický průzkum v roce 1990 nevyloučil možnost existence dvou parcel, a to na základě půdorysného zalomení zdi při uliční stavební čáře a vnější obvodové zdi pravého traktu, jejíž průběh se směrem do dvora nápadně lomí (Muk-Urban 1990, 19). Hypotéza vychází z předpokladu, že v Českých Budějovicích převládaly dvoutraktové hloubkově orientované domy s charakteristickým bočním průjezdem na užší parcele (srov. Líbal-Muk 1969, 80). Výsledky archeologického výzkumu toto zjištění nepotvrdily a nic nenasvědčuje původnímu rozdělení na dvě samostatná a později sloučená městiště. Nepravidelný tvar parcely je dán na západní straně průběhem vodního toku vytvářejícího v těchto místech výrazný oblouk, který rovněž ovlivnil i průběh hradební zdi. Na severní straně je zalomení parcely způsobeno průběhem komunikace směřující k tzv. Solné (Vodní) brance.

Nejstarší archeologicky zaznamenanou stavbou je objekt polozemnice (suterénu) zachycený liniovou sondou 8 položenou ve středovém průjezdu domu. Objekt č. 1/93, prozkoumaný pouze zčásti na severní straně sondy v hloubce $140 \mathrm{~cm}$ od současného povrchu, se nacházel blíže k čelu parcely přibližně 2 až 3 metry od uliční čáry. Objekty tohoto typu, tehdy interpretované jako polozemnice, dnes považujeme za suterény s obytnou funkcí, nebo s funkcí skladovací prostory sklepa či zapuštěné komory (např. Vařeka 2002, 266-275). Z výplně tohoto objektu pocházejí nálezy keramiky (mimo jiné grafitové konvice se třmenovým uchem, hrnce se značeným dnem, který je zdoben rytými vlnovkami a vrypy, a torzo lahvovité nádoby), jež je možné bezpečně 
datovat do třetí třetiny 13. století. Se stavbou suterénu datačně souvisí dvojice odpadních jam obj. č. 4/93 a 5/93 prozkoumaných v sondě 6 , které obsahovaly po typologické stránce shodný soubor keramiky. Do stejné fáze je možné zařadit i blíže nedatovaný mělký oválný objekt 6/93 a nejstarší úpravu povrchu z lomového kamene a říčních valonů zjištěnou v sondě 5 (obr. 7).

Po zániku suterénu došlo k založení dřevěné stavby při uliční čáře na severní straně objektu, která zř́jmě plnila funkci obytnou, byt' doklady obývání jednoznačně potvrzeny nebyly (například nález otopného zařízení). V kontextu doby byla tato stavba interpretována jako stavba roubeného domu (Militký-Zavřel 1994, 220; Militký 1995, 82-84), byt’ nelze vyloučit ani to, že se jedná o základový trám či věnec pro jiný typ dřevohliněné konstrukce.

$\mathrm{S}$ touto stavbou může prostorově souviset zachycené nároží zděné stavby z lomových kamenů na maltu tloušt'ky $70 \mathrm{~cm}$ zjištěné v jihovýchodním rohu sondy 5 , v hloubce $70 \mathrm{~cm}$ od současného povrchu. Z vrstev, do nichž se zděné konstrukce zahlubují, pocházejí nálezy keramiky datované k závěru 13. století. Nabízí se možná interpretace této stavby jako samostatně stojící zděné komory či špýcharu nacházejícího se ve střední části parcely, mělce zahloubené pod současnou úroveň terénu.

Umístění staršího zděného objektu v hloubi parcely není v Českých Budějovicích neobvyklé. Také v prrípadě výzkumu na nádvoří radnice v Českých Budějovicích byla odkryta zděná, samostatně stojící stavba ve střední části parcely, datovaná bezpečně do první poloviny 14. století, jež plnila hospodářskou funkci (Čapek-Militký a kol. 2016, 75). Se zděnými stavbami v hloubi městských parcel, které vesměs plnily funkci hospodářskou a skladovací (komora), se setkáváme i v jiných městech, kde jsou vesměs datovány do pokročilého 14. století na základě výsledků stavebně historických a archeologických výzkumů (srov. Muk 1978, 164-169; Bláha-Frolík-Sigl 2006, 178-187; Peška-Merta 2009, 94). V německých oblastech se jedná o zděné stavby v hloubi parcely označované jako Steinwerk a Kemenate, doložené již od druhé poloviny 12. století, které jsou funkčně připojeny k rozsáhlejšímu hrázděnému nebo dřevěnému domu a vytvářejí typickou dvojdílnou dispozici - Doppelhausform (Radová-Štiková 1991, 100; Hauserová 1995, 46; srov. zahraniční př́íklady Rötting 1994, 40-54; Löbbecke 2005, 16-25; 2006, 6-17; Rieger 2010, 117-119).

To však nebude tento případ. Zděná stavba prostorově ani osově přímo nenavazovala na dřevěný dům v čele parcely a byla pravděpodobně volně stojící stavbou. Rozsah dřevěné konstrukce směrem do hloubi parcely vymezuje umístění oválné jímky č. 2 v sondě 7 , která se nacházela př́mo za dřevěnou stavbou. Z její výplně pochází kolekce keramiky z konce 13. století. Jímka byla tedy nejspíše již zasypána před založením konstrukce dřevěné stavby. Později byla do tohoto staršího objektu vyhloubena jímka mladší, datovaná podle zásypu nejdříve do druhé poloviny 14. století. Pozice jímek ukazuje, že dřevěná stavba mohla mít do hloubky parcely maximální délku 4 až 5 metrů, a nebyla tak nikterak dispozičně spojena se zděnou stavbou ve středu parcely. Předpokládaný vstup do dřevěné stavby se mohl nacházet na východní straně v místech předpokládaného středověkého průjezdu.

Zánik dřevěné stavby můžeme na základě keramiky klást nejpozději do poloviny 14 . století. Nelze vyloučit, že s likvidací dřevěných konstrukcí souvisí nálezy úlomků dřev obsažených v hnojových vrstvách v zadní části parcely v sondě 2 (s. j. 2010, 2009), které časově korespondují $\mathrm{s}$ koncem zániku dřevěné stavby. Po zániku této stavby došlo krátce poté k výstavbě zděného domu, nejdříve po polovině 14. století. Sonda 9 odhalila základy zděné konstrukce (s. j. 9009), založené na úrovni vrstvy s. j. 9004 prokazatelně středověkého stáŕí, již je možné spojit s levým nárožím pravého bočního traktu domu. Na polohu staršího dřevěného domu tak prostorově navazovaly mladší konstrukce pravého zděného traktu, jenž je podle výsledků stavebně historického průzkumu nepochybně gotického stáŕí (Muk-Urban 1990, 14). Otázkou je vztah pravého předního bočního traktu k zadnímu příčnému traktu, který byl považován za dodatečně přistavěný někdy v průběhu 17. století (Muk-Urban 1990, 19). Výsledky archeologického výzkumu ukázaly na složitější stavební vývoj příčného zadního traktu, jehož základem se stala zděná stavba s velkou pravděpodobností již gotického stáŕí, zjištěná $\mathrm{v}$ sondě 5 , k níž byly později přistavěny mladší konstrukce, které pak vytvořily celkovou dispozici prričného trojprostorového traktu zasahujícího přes celou širřku parcely. 
Podle výsledků stavebně historického průzkumu gotický dům vznikl po polovině 14 . století. Mezi pozůstatky obvodových gotických konstrukcí náleží, kromě pravého předního traktu, také nápadně zesílená zed'v uličním průčelí levého traktu (obr. 8). Ze stavebně historického průzkumu rovněž vyplývá, že se původně jednalo o síňový dům, který byl v novověku rozdělen vstupní chodbou a levým bočním traktem. Konečnou hloubkovou trojtraktovou dispozici se středovým průjezdem získal dům během přestavby v roce 1780 (Muk-Urban 1990, 20). K dalším dílčím úpravám interiéru domu došlo až v klasicistním období. V této podobě bez výraznějších stavebních úprav ve 20. století se měštanský dům dochoval až do počátku 90. let, kdy byly rozhodnuto o jeho necitlivém zbourání, přestože se jednalo o památkově chráněný objekt od roku 1958 . $^{3}$ Z původního domu bylo zachováno pouze průčelí při uliční čáře.
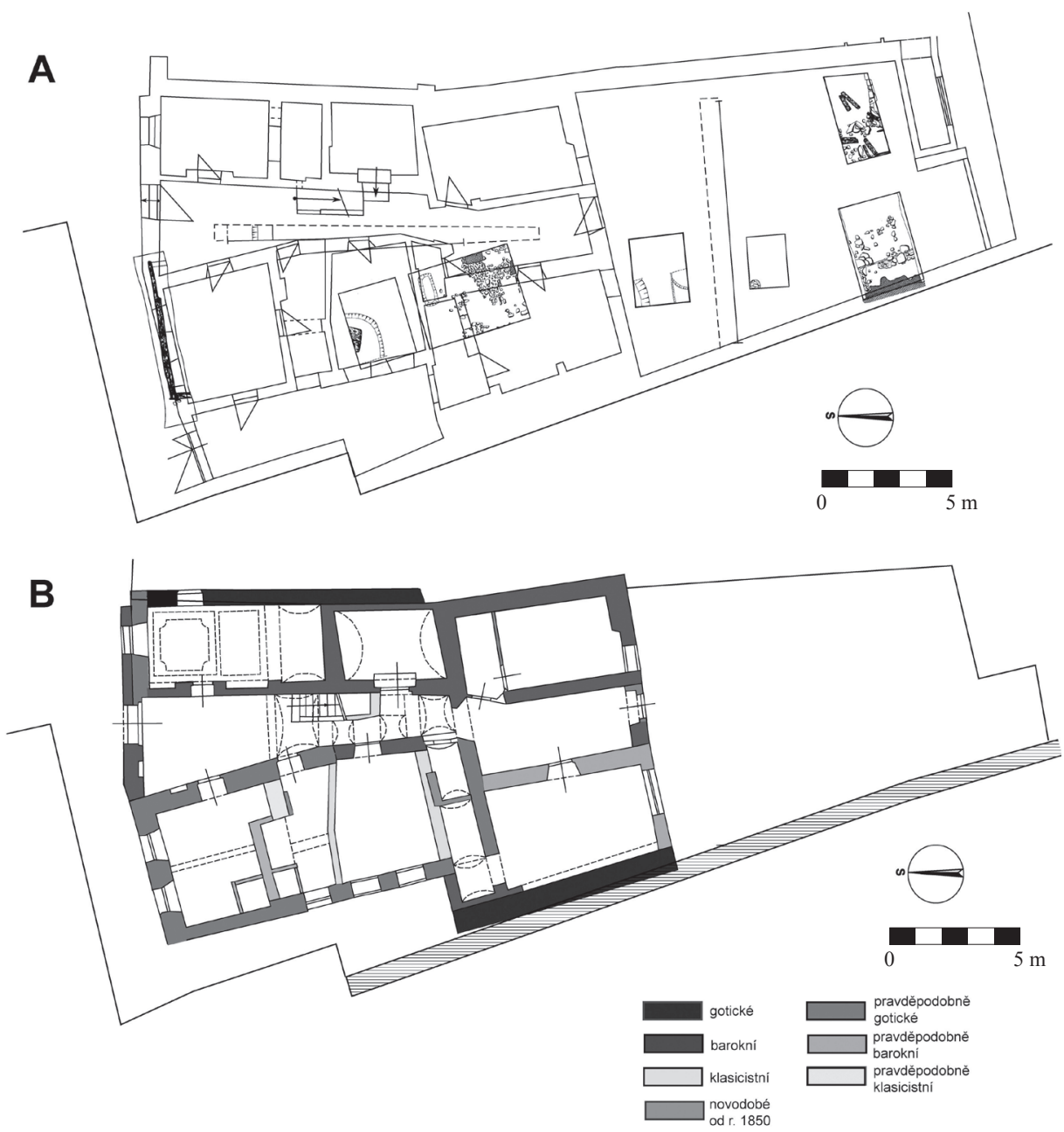

Obr. 8. A - zakreslení archeologicky zjištěných situací první a druhé fáze do půdorysu přízemí domu; B - datování konstrukcí v přizemí domu podle stavebně historického průzkumu. Upravil L. Čapek.

Abb. 8. A - im Grundriss des Erdgeschosses des Hauses eingezeichnete archäologisch festgestellte Situationen der ersten und zweiten Phase; B - Datierung der Konstruktion im Erdgeschoss des Hauses gemäß bauhistorischer Untersuchung. Bearbeitung L. Čapek.

3 Viz https://www.pamatkovykatalog.cz/mestansky-dum-2342411. 


\section{Doklady dřevohliněné architektury ve městě}

Nejstarší lokační stavby, které vznikaly na českobudějovických městských parcelách po založení města $\mathrm{v}$ roce 1265 , představují zahloubené objekty suterénů, dříve považované za polozemnice (srov. Militký-Zavřel 1994; Militký 1995). Užitná plocha suterénů se pohybuje kolem 20 až $25 \mathrm{~m}^{2}$ a některé z nich byly př́ístupné vstupní šíjí. Jejich zahloubení do podloží dosahovalo kvůli vyšší hladině podzemní vody maximálně do úrovně kolem 1 metru. Poloha suterénů na městských parcelách je značně variabilní, setkáváme se ponejvíce s objekty ve střední a zadní části parcely (obj. 1/3 v Hroznové čp. 470/13, obj. 5/8 U Černé věže čp. 66/3, obj. 3/1 na náměstí Přemysla Otakara II. čp. 58/16, obj. 4/2 na nádvoří radnice) a výjimečně se suterény, které se nacházely v čele parcel při uliční čáře (obj. 3/1 v Hroznové čp. 470/13), které již respektovaly původní parcelaci. V žádném z objektů se dosud nepodařilo prokázat jejich primární obytnou funkci, řada z nich plnila zřejmě funkci skladovací komory či sklepa (Valkony 2001, 75-77; Kovář 2015, 95-97; Lavička-Čapek 2016, 358; srov. Vařeka 2002, 271-273). Ve vzácných případech se dochovaly pozůstatky dřevěných konstrukcí v podobě fošen z obložení stěn a pozůstatků vydřevených podlah. Např́iklad ze suterénů obj. 3/1 v Hroznové ulici čp. 470/13 a obj. 3/1 na náměstí Přemysla Otakara II. čp. 58/16 pocházejí pozůstatky dřevěných konstrukcí datované do třetí třetiny 13. století. Zuhelnatělé dřevěné konstrukce a přepálené bloky mazanice, které prošly žárem, pocházejí ze zaniklého suterénu v Kněžské ulici čp. 97/1 a na náměstí Přemysla Otakara II. čp. 89/27 (MilitkýZavřel 1994, 219; Militký 1995, 80-81; Valkony 2001, 67-68; Lavička-Čapek 2016, 255-258). Českobudějovické suterény vykazují poměrně málo indicií možné podoby nadzemních dřevohliněných konstrukcí. Sloupové jámy, které by mohly nést nadzemní konstrukce, byly zjištěny pouze u suterénu v Kanovnické ulici čp. 375/3 (Zavřel 1997, 31-32). Českobudějovické suterény přestaly sloužit svému účelu na přelomu 13. a 14. století, kdy došlo k jejich postupnému zániku. V jejich výplních zaznamenáváme postupné ukládání tenkých postupně proklesávajících vrstev, z nichž některé je možné interpretovat jako spáleništní. Pouze v ojedinělých př́ípadech zaznamenáváme jednorázové zasypání destrukčním materiálem (Valkony 2001, 76).

Rané doklady parcelace tvoří pozůstatky původního dřevěného oplocení, které se dochovalo na řadě archeologicky zkoumaných parcel (nám. Přemysla Otakara II. čp. 49/13, 58/16, 84/24, Hroznová čp. 63/5, Česká čp. 232/21), a to jak v podobě souvislých řad negativů po kůlových jamkách, tak i přímo pozůstatků po dřevěných či zuhelnatělých kůlech, které byly vyplétány pruty (Militký 1995, 80-83; 1997, 28-29; Zavřel 1998, 34; Lavička-Čapek 2016, 255). V zadních částech parcel byly $\mathrm{v}$ několika případech objeveny pozůstatky hospodářských staveb lehčích kủlových konstrukcí. Jednalo se zejména o nejrůznější chlévy, dřevníky a další přístřešky. Kůlové jamky vymezující půdorys těchto drobných staveb byly zjištěny na náměstí Přemysla Otakara II. čp. 84/24, v Krajinské čp. 280/42 a v Hroznové čp. 159/23 na ploše dvora mezi Hroznovou ulicí a pozdně gotickou solnicí (Militký 1995, 83; Havlice 2004, 41; Kovář 2015, 97).

Pozůstatek dřevěné (srubové) konstrukce v Radniční ulici čp. 138/11 je dosud jediným př́́kladem archeologicky doložené dřevohliněné architektury, která vývojově navazovala na zahloubené objekty suterénů. Nelze vyloučit, že dřevěná konstrukce je základem pro jiný typ dřevěné konstrukce než roubené. Bohužel partie předních částí parcel byly v mnohém případě zničeny mladší výstavbou zděných jader pozdějších gotických a renesančních domů, nebo při hloubení sklepů. Spálené destrukce nadzemního domu ze 14. století pocházejí např́íklad z České ulice čp. 232/21, ovšem dosud bez podrobného vyhodnocení (Zavřel 1998, 34). Pozůstatky dřevohliněné konstrukce neznámého účelu zahloubené pod úroveň terénu byly objeveny při záchranném výzkumu městské solnice na Piaristickém náměstí. Stavba zanikla požárem v průběhu třetí třetiny 13. století. Nabízí se souvislost dřevohliněného objektu s blízkým areálem dominikánského konventu; je dosud nejstarší datovanou dřevěnou stavbou ve městě (Thomová a kol. 2019, 300-304).

Podobně jako v řadě jiných měst v Čechách a na Moravě lze předpokládat, že v Českých Budějovicích převažovaly na přelomu 13. a 14. století roubené stavby měštanských domů, nelze však vyloučit i podíl jiných typů konstrukcí, například hrázdění (srov. Líbal-Muk 1969, 59). 
Novější archeologické výzkumy jiných měst v Čechách a na Moravě prokazují i podíl jiných typů konstrukcí - např́íklad rámové, sloupkové, drážkové apod. (Vařeka 2002, 256-258; Holub a kol. 2005, 53). Je jen škoda, že dosud nebyla v Českých Budějovicích větší pozornost věnována rozboru mazanicových otisků, které by mohly blíže objasnit typy konstrukcí nejstarších dřevěných městských domů (srov. Nováček-Vařeka 1997; Kaiser a kol. 2005, 102-117; Netolický 2010; Zůbek 2019).

Roubené a vydřevené konstrukce se dochovaly $\mathrm{v}$ několika případech městských domů $\mathrm{v}$ prvním patře jako součást obytných interiérů světnic, jejichž funkce spočívala především v zateplení místností. Například při stavebně historickém průzkumu domu čp. 456/37 v Široké ulici byl v roce 1986 v polopatře jednoprostorového domu objeven roubený srub z kuláčů krytých zvnějšku hliněným omazem a zasahující částečně do prostoru krovu. Horní části podélných stěn se segmentově sbíhaly na způsob valené klenby podpírající plochý strop z kuláčů, které nesly tři prríčně položené hraněné trámy na způsob hambalků, přičemž u středního byla podpůrná funkce posílena vystupujícím dřevem. Dendrochronologicky je srubová konstrukce datována do prvního desetiletí 15. století, použité stromy byly smýceny v rozmezí let 1406-1409 (Líbal-Stach 1962, 442; Muk-Urban 1988, 102-104, obr. 5; Škabrada 2003, 86; Kovář ed. 2016, 32-34).

Srubová konstrukce s mazanicovým omazem byla zjištěna v roce 1994 také v prvním patře domu v Panské ulici čp. 168/14. Stěny místnosti jsou roubené na rybinu z kuláčů, které kryla zvenčí izolace z hliněné omazávky nesená zatlučenými kolíčky do stěn. Původní je i strop z překládaných desek, které nesly dva příčně položené hraněné trámy. Podlaha z fošen spočívala na trámech stropu v přízemí. Datování srubové konstrukce je kladeno do 15.-16. století (Líbal-Stach 1962, 384; Militký 1995, 81; Kovář ed. 2016, 34-35).

Dosud nejstarší dřevěnou konstrukci se podařilo odhalit při průzkumu domu v Kanovnické ulici čp. 76/2. Při odstraňování násypů kleneb nad přízemím bylo v prvním patře objeveno torzo čtyř prahových trámů a jednoho průvlaku s dekorativní polychromií datovaných dendrochronologicky do let 1344-1345. Na severní a západní straně světnice bylo objeveno autentické osazení trámů v obvodové zdi a při odstraňování novodobých vrstev byl okryt obvodový dřevěný rám konstrukce podlahy. Datace konstrukce výdřevy světnice je dendrochronologicky datována do let 1441-1442 (Musil 2016, 288-294).

\section{Závěr}

Záchranný archeologický výzkum čp. 138/11 v Radniční ulici prokázal rané osídlení parcely krátce po založení města v roce 1265 . Jednalo se o parcelu, která se nacházela nedaleko soutoku Vltavy a Malše. Půdorys parcelního bloku v této části města ovlivnil jak průběh vodního toku Vltavy, tak průběh komunikace směřující $\mathrm{k}$ Solné brance umožňující př́stup k vodě a budované městské opevnění, jehož výstavbu lze předpokládat ke konci 13. a počátku 14. století (ČechuraRazím 1988, 409; Lavička-Čapek 2016, 252-254).

Nejpozději v závěru 13. století byla založena v severní části parcely dřevěná stavba respektující v půdoryse uliční čáru komunikace. Jejím pozůstatkem je základový trám s dvojící bočních nároží spojených na rybinu, vytvářející pravoúhlý půdorys. Stavba byla k uliční čáře orientována štítově a nepochybně plnila funkci obytnou. Vývojově navazovala na starší objekt suterénu, který se rovněž nacházel blíže k čelu parcely. Dotčená stavba je jedním ze vzácných dokladů existence dřevěné fáze dřevohliněných domů v první polovině 14. století a vývojovým stupněm mezi nejstaršími objekty suterénů a zděnými gotickými domy, které vznikají již možná před polovinou 14. století. Absence nálezů mazanice v zánikové vrstvě 9002 , která by mohla pocházet z nadzemních konstrukcí, lze vysvětlit tím, že dřevěná obytná stavba bud' nebyla omazána, nebo neprošla požárem, který by zachoval charakteristické otisky. Nelze rovněž vyloučit, že zjištěná dřevěná konstrukce, interpretovaná jako pozůstatek srubového domu, může být základem i pro jiný druh užité dřevěné konstrukce, například rámové. Tyto konstrukce však z prostředí města z dosavadních archeologických výzkumů zatím neznáme. Jejich existenci by mohly objasnit také 
rozbory mazanicových otisků, kterým dosud v prrípadě Českých Budějovic nebyla věnována větší pozornost.

Počátky nejstarších domů nově založených měst ve 13. století patří k důležitým tématům medievální archeologie. Nadzemní profánní dřevohliněná architektura uniká v našem prostředí z archeologické evidence kvůli horším podmínkám dochování a také fragmentárnosti pozůstatků. Pozůstatky dřevěných základových konstrukcí nadzemních domů, podsklepených i nepodsklepených, byly prokázány zejména ve městech, kde jsou příznivější podmínky pro jejich dochování díky podloží, např́íklad v Hradci Králové (Sigl-Vokolek 1992, 83; Richter-Vokolek 1995, 121-123; Bláha 2005, 118-124), Olomouci (Bláha 1999, 189-213), Brně (Holub a kol. 2005, 5, 61-64) či Opavě (Skalická-Marethová 2013, 253-271). Ve většině případů byly doloženy roubené, sloupové, drážkové a rámové konstrukce a výjimečně i jiné stavební techniky. Např́klad v Plzni v čp. 289 byly zjištěny doklady pro existenci lokačního hrázděného domu, jehož pravděpodobnou rekonstrukci upřesnil až rozbor mazanicových otisků (Nováček-Vařeka 1997).

Datování zániku stavby je založeno na rozboru keramických nálezů, jejichž skladba odpovídá první polovině 14 . století, kdy se souběžně s doznívající grafitovou keramikou objevuje již nejstarší redukční keramika nepř́liš kvalitního výpalu. Soubor keramiky obsahoval mimo jiné vzácné doklady importů v podobě nálezu okraje miniaturní nádoby z jemně bělavé kaolinitické hmoty a hnědé kameniny německé provenience. Tyto nálezy jsou dokladem kontaktů rozvíjejícího se města s regiony na západ od našich hranic, a do prostředí měštanských domácností se dostávaly prostřednictvím obchodních vztahů.

Článek vznikl v rámci projektu NAKI II - Vrcholně středověká keramika jako součást movitého kulturního dědictví DG18P02OVV020.

\section{Literatura}

BEUTMANN, J.-KENZLER, H., 2006: Weiße Miniaturgefäße des 12. bis 14. Jahrhunderts aus Sachsen in ihrem überregionalen Kontext, Arbeits- und Forschungsberichte zur sächsischen Bodendenkmalpfleg 46/2004, 485-494.

BLÁHA, J., 1999: Archeologické poznatky ke stavební konstrukci nejstarších měštanských domů v Olomouci - Archäologische Erkenntnisse zur Baukonstruktion der ältesten bürgerlichen Häuser in Olomouc (Olmütz), AH 24, 189-213.

- 2005: „Zemnice“ v Hradci Králové. Dosavadní stav poznání. In: Forum Urbes Medii Aevi II. Sborník př́ispěvků z 2. ročníku odborného semináře konaného 16.-18. dubna 2003 v Brně, 118-125. Brno.

BLÁHA, R.-FROLÍK, J.-SIGL, J., 2006: Počátky zděné měš’’anské architektury v Hradci Králové a v Chrudimi - Anfänge gemauerter Bürgerarchitektur in Hradec Králové und Chrudim. In: Forum Urbes Medii Aevi III. Vrcholně středověká zděná měštanská architektura ve střední Evropě. Sborník př́íspěvků z konference FUMA konané 14.-16. 4. 2004 v Jihlavě, 178-189. Brno.

ČAPEK, L.-MILITKÝ, J. a kol., 2016: Historická radnice v Českých Budějovicích ve světle archeologických výzkumů a rozboru hmotných pramenů. Plzeň - České Budějovice.

ČECHURA, J.-RAZÍM, V., 1988: K některým aspektům vývoje půdorysu a opevnění Českých Budějovic do počátku 15. století, Památky a prŕroda 13, 407-415.

ERNÉE, M.-VAŘEKA, P., 1998: Die Graphitton-keramik des 13. Jahrhunderts in Süd-böhmen und Prag. In: Frühmittelalterliche Graphittonkeramik in Mitteleuropa. IV, Internationale Tagungen in Mikulčice (Poláček, L., ed.), 217-230. Brno.

HOFFMANN, Y., 1995: Waldenburger Steinzeug des 14. Jahrhunderts. In: Forschungen zu Baugeschichte und Archäologie. Heft 5 (Schwabenicky, W., ed.), 43-96. Mittweida.

HOLUB, P. a kol., 2005: Holub, P.-Kolařík, V.-Merta, D.-Peška, M.-Zapletalová, D.-Zůbek, A., Ke stavu poznání nezděné měštanské architektury vrcholně středověkého Brna. In: Forum Urbes Medii Aevi 
II. Sborník příspěvků z 2. ročníku odborného semináře konaného 16.-18. dubna 2003 v Brně, 44-101. Brno.

HAUSEROVÁ, M., 1995: Středověký měšt’anský dům na široké parcele se středním vjezdem (Příspěvek k poznání dispozičního typu) - Mittelalterliches Stadthaus auf einer breiten Parzelle mit dem Hausflur in der Mitte, AH 20, 35-52.

HAVLICE, J., 2004: České Budějovice. U1. Hroznová 23. In: Výzkumy v Čechách 2002, 41. Praha.

HRDLIČKA, L.-RICHTER, M.-SMETÁNKA, Z., 1966: Výzkum v Sezimově Ústí v r. 1965, AR XVIII, 663-680.

KAISER, L. a kol., 2005: Kaiser, L.-Kočár, P.-Postránecká, K.-Široký, R., 2005: Požárem zaniklý středověký objekt ve Smetanově ulici ve Starém Plzenci. In: Forum Urbes Medii Aevi II. Sborník př́íspěvků z 2. ročníku odborného semináře konaného 16.-18. dubna 2003 v Brně, 102-117.

KLÁPŠTĚ, J., 1983: Studie o středověké studně z Mostu - Studie über einen mittelalterlichen Brunnen aus Most, PA LXXIV, 443-492.

KLÁPŠTĚ, J. a kol., 2002: Archeologie středověkého domu v Mostě (čp. 226). Praha - Most.

KOVÁŘ, D., 2015: Fundatio civitatis - zrození královského města Českých Budějovic. České Budějovice.

KOVÁR̆, D., ed., 2016: Slavné stavby Českých Budějovic. České Budějovice.

KUBÁK, J., 1973: Topografie města Českých Budějovic 1540-1800. České Budějovice.

LAVIČKA, R.-ČAPEK, L., 2016: Královské město České Budějovice. In: Lavička, R., Královská založení na jihu Čech za vlády posledních Přemyslovců, 219-266. České Budějovice.

LÍBAL, D.-STACH, E., 1962: České Budějovice, průvodní zpráva k stavebně-historickému průzkumu historického jádra, rozmnožený rukopis. SÚRPMO Praha. Archiv Archeologického oddělení Jihočeského muzea, České Budějovice.

LÍBAL, D.-MUK, J., 1969: Domy a opevnění v Českých Budějovicích v gotice a renesanci. In: Minulost a současnost Českých Budějovic, 57-74. České Budějovice.

LÖBBECKE, F., 2005: Hochmittelalterliche Holz-Stein-Bauten in Südwestdeutschland und der Nordschweiz. In: Forum Urbes Medii Aevi II. Sborník příspěvků z 2. ročníku odborného semináře konaného 16.-18. dubna 2003 v Brně, 16-25. Brno.

- 2006: Steinere Wohnbauten des 12. und 13. Jahrhunderts in Freiburg im Breisgau. In: Forum Urbes Medii Aevi III. Vrcholně středověká zděná měšt’anská architektura ve střední Evropě. Sborník př́íspěvků z konference FUMA konané 14.-16. 4. 2004 v Jihlavě, 178-189, 6-7. Brno.

MILITKÝ, J., 1993: Nálezová zpráva o záchranném archeologickém výzkumu na lokalitě: České Budějovice, Radniční ulice čp. 11. Archiv Archeologického oddělení Jihočeského muzea, České Budějovice.

- 1995: Archeologické výzkumy v Českých Budějovicích, Výběr - časopis pro vlastivědu jižních Čech 32/2, 77-85.

- 1997: Dvůr domu čp. 13 na nám. Přemysla Otakara II. In: Výzkumy v Čechách 1993-1995, 28-29. Praha.

MILITKÝ, J.-ZAVŘEL, P., 1994: Archeologické výzkumy v historickém jádru Českých Budějovic v roce 1993. In: Mediaevalia Archaeologica Bohemica 1993. Památky archeologické - Supplementum 2, 219-221. Praha.

MUK, J., 1978: Přínos stavebně historického a archeologického výzkumu Mostu k dějinám městského domu - Beitrag der baugeschichtlichen und archäologischen Untersuchung von Most zur Geschichte des Stadthauses, AH 3, 165-169.

MUK, J.-URBAN, J., 1988: O koncepci dalšího výzkumu městských domů k sociálně ekonomické struktuře městské zástavby v Českých Budějovicích ve středověku - Über die Konzeption weiterer Erforschung von Bürgerhäusern und über die sozialökonomische Struktur der Stadtbebauung von České Budějovice im Mittelalter, AH 13, 97-105.

- 1990: České Budějovice - stavebně historický průzkum. Radniční čp. 416 (st. č. 11). SÚRPMO Praha. Rukopis ulož. v archivu NPÚ, ú. o. p. v Českých Budějovicích.

MUSIL, V., 2016: Nové poznatky o stavebním vývoji měšt’anského domu v Českých Budějovicích, Kanovnická čp. 76/2. In: Počátky měst a městeček v jižních Čechách. Sborník př́íspěvků k dějinám urbanizace jihočeského regionu. Jihočeský sborník historický - Supplementum 7, 288-294. České Budějovice. 
NETOLICKÝ, P., 2010: Dřevohliněné konstrukce z vrcholně středověké Chrudimi, Chrudimský vlastivědný sborník 14, 69-128.

NOVÁČEK, K.-TETOUR, M., 2003: K použití deskripčních databází v archeologii - keramická databáze Klasiker. Dostupné z: www.kar.zcu.cz/texty, cit. 10. 11. 2020.

NOVÁČEK, K.-VAŘEKA, P., 1997: Pozůstatky lokačního domu čp. 289 v Plzni. Méně známá stavební tradice v Čechách vrcholného a pozdního středověku. In: Život v archeologii středověku (Kubková, J. a kol., ed.), 488-497. Praha.

PAMÁTKOVÝ KATALOG - Národní památkový ústav. Dostupné z: https://www.pamatkovykatalog.cz/ mestansky-dum-2342411, cit. 18. 11. 2020.

PEŠKA, M.-MERTA, D., 2009: Měštanská architektura středověkého Brna v kontextu stř̌edního Podunají. In: Trnava a počiatky stredovekých miest. Pamiatky Trnavy a Trnavského kraja 12, 87-102. Trnava.

PROCHÁZKA, R., 2007: Deskripční systém brněnské keramiky. Příloha 1, PV 48, 234-270.

RADOVÁ-ŠTIKOVÁ, M., 1991: Ke stavební technologii středověkého domu, Husitský Tábor 10, 97-102.

RIEGER, D., 2010: Platea finalis. Forschungen zur Braunschweiger Altstadt im Mittelalter. Beiträge zur Archäologie in Niedersachsen 15. Rahden/Westf.

RICHTER, M., 1982: Hradišt'ko u Davle. Městečko ostrovského kláštera. Praha.

RICHTER, M.-KRAJÍC, R., 2001: Sezimovo Ústí. Archeologie středověkého poddanského města, 2. Levobřežní předměstí - archeologický výzkum 1962-1988. Archeologický ústav AV ČR. Praha.

RICHTER, M.-VOKOLEK, V., 1995: Hradec Králové, slovanské hradiště a počátky středověkého města. Hradec Králové - Praha.

RÖTTING, H., 1994: Das ostsächsiche Doppelhaus des hohen Mittelalters im archäologisch-rechthistorischen Befund von Braunschweig. In: Hausbau und Raumstruktur früher Städte in Ostmitteleuropa (Brachmann, H.-Klápště, J., edd.), 40-54. Prag.

SCHIEDEMANTEL, D.-SCHIFER, T., 2005: Waldenburger Steinzeug, Archäologie und Naturwissenschaften. In: Veröffentlichungen des Landesamtes für Archäologie mit Landesmuseum für Vorgeschichte. Band 44 (Oexle, J., ed.). Dresden.

SIGL, J.-VOKOLEK, V., 1992: Výzkum Velkého námětí v Hradci Králové - Erforschung des Großen Marktes in Hradec Králové, AH 17, 83-90.

SKALICKÁ, P.-MARETHOVÁ, B., 2013: Středověká dřevohliněná zástavba domovního bloku - předběžné shrnutí výsledků předstihového výzkumu v prostoru bývalé Radniční ulice v Opavě, ČSZM B 62 , 253-271.

ŠKABRADA, J., 2003: Konstrukce historických staveb. Praha.

THOMOVÁ, Z. a kol., 2019: Thomová, Z.-Kocina, J.-John, J.-Kováŕ, D., Záchranný archeologický výzkum budovy solnice na dnešním Piaristickém náměstí v Českých Budějovicích - Die Rettungsgrabung im Salzhaus am Piaristenplatz in České Budějovice, AVJČ 32, 275-314.

VALKONY, J., 2001: Zástavba středověkých parcel v Českých Budějovicích. Rukopis diplomové práce ulož. na Katedře archeologie Filozofické fakulty Západočeské univerzity v Plzni, Plzeň.

VAŘEKA, P., 1993: Povrchový průzkum hradu Př́iběničky (okr. Tábor), CB 3, 95-110. Praha.

- 1998: Proměny keramické produkce vrcholného a pozdního středověku v Čechách - The erratic character of ceramic production in the High and Later Middle Ages in Bohemia, AR L, 123-137.

-2002: Zahloubené stavby v českých městech vrcholného středověku - zemnice nebo suterény nenalezených nadzemních domů. In: Neustupný, E. (red.), Archeologie nenalézaného. Sborník přátel, kolegů a žáků k životnímu jubileu Slavomila Vencla, 254-285. Plzeň.

ZAVŘEL, P. 1997: České Budějovice, Hroznová ul. 7/62. In: Výzkumy v Čechách 1993-1995, 29. Praha.

- 1997: Kanovnická ul. čp. 3, ppč. 465. In: Výzkumy v Čechách 1993-1995, 31-32. Praha.

- 1998: Dvůr domu čp. 21 v České ulici. In: Výzkumy v Čechách 1996-1997, 34. Praha.

- 2018: 25 let archeologického oddělení Jihočeského muzea v Českých Budějovicích, AVJČ 31, 379-398.

ZŮBEK, A., 2019: Mazanice - stavební materiál v brněnském prostředí: př́íkladová studie zpracování a analýzy souboru fragmentů vypálené mazanice z výplní suterénu VS029 na parcele domu Kobližná 4. Brno. 


\section{Zusammenfassung}

\section{Die Holzkonstruktion eines Hauses aus České Budějovice aus der ersten Hälfte des 14. Jahrhunderts}

Der vorliegende Beitrag beschäftigt sich mit der Auswertung eines bei einer im Jahr 1993 in České Budějovice auf der Parzelle Nr. 138/11 in der Straße Radniční durchgeführten archäologischen Grabung entdeckten Fundes der Holzkonstruktion eines Hauses. Die dokumentierte Konstruktion in Fundamentsondierschnitt Nr. 9 befand sich an der Straßenflucht vor der Hausfront und bestand aus einem $4 \mathrm{~m}$ langen Kantbalken, an dessen Enden zwei weitere, durch Zapfenverbindung miteinander verbundene Querbalken anschlossen. Die Gründung der Konstruktion wurde in einer fünfzig bis sechzig Zentimeter tiefen Aushebung angelegt, deren Verfüllung aus einer dünnen Fußbodenlehmschicht (Schicht 9001) und einer Lehm-Sand-Verfüllung (Schicht 9002) aus der Zeit bestand, als das Objekt aufhörte zu existieren. Aus den Schichten wurden Bruchstücke mittelalterlicher Keramik geborgen, welche die Entstehung des Baus in die erste Hälfte des 14. Jahrhunderts datieren. Neben der üblichen Gebrauchskeramik heimischer Produktion wurden zwei Keramikimporte ausländischer Provenienz entdeckt (Bruchstück des Randes eines Miniaturgefäßes aus fein geschwemmter weißlicher Masse und der Hals eines Steingutgefäßes, offenbar eines Krugs). Aus der Verfüllung des Objektes stammt auch die Klinge eines Eisenmessers.

Die Holzkonstruktion gehörte zu einem Wohnhaus im vorderen Teil der Parzelle, das entwicklungsmäßig an ein älteres Objekt im Souterrain aus der Gründungszeit der Stadt nach 1265 anknüpft, das in Sondierschnitt 8 im vorderen Teil der Parzelle entdeckt wurde. Aufgrund der geringeren Eintiefung von maximal $60 \mathrm{~cm}$ unter der ursprünglichen Oberfläche ziehen wir auch eine oberirdische Hauskonstruktion in Betracht. Die Holzkonstruktion wurde demnach als Überrest eines Blockbaus interpretiert, jedoch kann nicht ausgeschlossen werden, dass es sich auch um das Fundament für einen anderen verwendeten Konstruktionstyp handelt - beispielsweise um eine Rahmenkonstruktion. Leider enthielt die Verfüllung des Objektes keine Schlüsselfunde von Lehmbewurfabdrücken, die den Charkater der angenommenen Holz-Lehm-Konstruktion präzisieren würde.

Die zu klärende Frage ist der Bezug dieser Holzkonstruktion zu den anderen auf der Parzelle befindlichen Objekten und Konstruktionen. Mit dem Holzbau zeitlich zusammenhängen kann die Ecke eines Steinbaus, die im Mittelteil der Parzelle entdeckt wurde (Sondierschnitt 5), deren Datierung aufgrund der Keramikfunde in die erste Hälfte des 14. Jahrhunderts gelegt werden kann. Der Steinbau hat die Funktion eines Wirtschaftsobjektes erfüllen können (hintere Steinkammer), das an das Holzwohnhaus im vorderen Teil räumlich anschloss. In diesem Fall könnte man hier die Bauform eines oberirdischen Stadthauses in Betracht ziehen, das aus einem Wohnteil aus Holz (Blockhütte) und einer daran anschließenden gemauerten Kammer bestand. Analoge Beispiele für solche Häuser (vom Typ Doppelhausform) findet man besonders in Deutschland. Einen Bezug zwischen diesen Objekten schließt jedoch die Lage der Sickergrube in Sondierschnitt 7 aus, die gleichzeitig die Länge des Holzbaus in Richtung Parzellentiefe abgrenzt, die höchstens $5 \mathrm{~m}$ betragen haben muss. Beide Objekte waren demnach eher voneinander abgetrennt.

In České Budějovice begegnen wir nur selten Überresten der ältesten Holzkonstruktionen, die vornehmlich die Verkleidung von eingetieften Bauten in Souterrains aus dem dritten Drittel des 13. Jahrhunderts, frühe Parzellenumzäunungen oder Überreste von Wirtschaftsbauten aus leichteren Holzkonstruktionen bilden. Eine analoge Konstruktion eines oberirdischen Hauses wurde bislang nicht entdeckt, besonders deswegen, weil ihre Überreste in den vorderen Parzellenteilen im Zusammenhang mit dem jüngeren Bau der gemauerten Kerne gotischer Häuser zertört wurden, wozu es laut den Ergebnissen von bauhistorischen Untersuchungen nach Mitte des 14. Jahrhunderts gekommen war. Die vorderen Teile von städtischen Parzellen sind bisher jedoch nur wenig archäologisch untersucht worden. Ein seltener Fall hierfür sind zwei erhalten gebliebene Beispiele von Holzkonstruktionen, die eine gezimmerte Wärmeisolierung von Wohnräumen 
bildeten (Široká Konskriptionsnr. 456/37, Panská Konskriptionsnr. 168/14), von denen das erste Beispiel dendrochronologisch in das erste Jahrzehnt des 15. Jahrhunderts datiert wurde. Die bisher älteste dendrochronologisch datierte Konstruktion ist ein in die Jahre 1344-1345 datierter Holzfußboden des ersten Stocks von Haus Konskriptionsnr. 76/2 in der Straße Kanovnická, der die Existenz von oberirdischen Holzhäusern für die Zeit um Mitte des 14. Jahrhunderts bestätigt.

Der Holzbau ist ein seltener Beleg für die kurze Etappe der Existenz einer offenbar bereits oberirdischen städtischen Holzarchitektur in České Budějovice, die an die ältesten Souterrainobjekte anknüpfte und dem Bau von gemauerten gotischen Häusern an der Parezllenvorderseite vorausging, deren Datierung in die Zeit um Mitte des 14. Jahrhunderts gelegt wird. Weitere und moderner durchgeführte Grabungen sollten der Frage nachgehen, die in der vorliegenden Studie angerissenen räumlichen Bezüge detaillierter zu klären.

Der vorliegende Beitrag entstand im Rahmen des Förderprojekts NAKI II - Hochmittelalterliche Keramik als Bestandteil des beweglichen Kulturerbes DG18P02OVV020.

Mgr. Ladislav Čapek, Ph.D., Katedra archeologie Fakulty filozofické Západočeské univerzity, Sedláčkova 15, 30615 Plzeň, Česká republika, capekla@kar.zcu.cz

doc. PhDr. Jiří Militký, Ph.D., Národní muzeum, Vinohradská 1, 11000 Praha 1, Česká republika, jiri.militky@nm.cz 